\title{
Malignant Ovarian Neoplasm
}

National Cancer Institute

\section{Source}

National Cancer Institute. Malignant Ovarian Neoplasm. NCI Thesaurus. Code C7431.

A primary or metastatic malignant neoplasm involving the ovary. Most primary malignant ovarian neoplasms are either carcinomas (serous, mucinous, or endometrioid adenocarcinomas) or malignant germ cell tumors. Metastatic malignant neoplasms to the ovary include carcinomas, lymphomas, and melanomas. 